\title{
IIMIICONF
}

\section{Affinity of The Y Generation towards impulsive Buying}

\author{
Aleksandar Djordjević* and Aleksandar Jakšić \\ ${ }^{1}$ University of Belgrade, Faculty of Economics, Kamnička 6, 11.000 Belgrade, Serbia \\ *Corresponding author
}

\begin{abstract}
.
Impulsive buying, which has inevitably become part of our everyday life, represents an unplanned spending with aim to ensure the satisfaction of modern consumers. The act of impulsiveness depends on the individual and starts from pure impulsiveness (e.g. buying a new products) to the planned purchase of a certain category (but not a brand). In addition, impulsive purchase, like any other purchase, requires the existence of an unsatisfied need or desire that creates tension and an urge to behave. The goal of unplanned consumption is, with the existence of positive mood and excitement, satisfying this need and reducing tension. Through the act of impulsive buying, the whole motivation process in consumer awareness can be modeled, which is the fastest in this case. If the consumers are the members of the Y generation then this process is further enhanced by their main character traits, which can be encompassed in prioritizing personal goals and ambitions. Because of this, the behavior and psychological frame of $Y$ generation are significantly complementary to the characteristics of impulsive buying, and in the marketing sense this generation is targeted as a specific market segment that requires a genuine marketing approach.
\end{abstract}

Keywords: Impulsive buying, consumer, Y generation, buying process

\section{Introduction}

Impulsive buying is one of the forms of consumer behavior which is important for the theoretical and practical analysis in marketing. Impulsive buying is the subject of a great number of research from the area of marketing which are aimed at defining the model of consumer behavior (Muruganantham \& Bhakat, 2013). The behavior of generation Y is also very important in marketing due to the fact that this segment of consumers shall have the decisive buying power in the next thirty and more years to come, so a great number of marketing strategies shall be aimed at them.

The term impulsive buying can be defined in multiple ways, but all definitions have in common that the consumer does not plan the act of buying before the very entry into the object or the visit to the e-shop (Tinne 2010). Impulsive buying does not appear only as a consequence of irrational consumer behavior, but is also influenced by numerous internal and external 


\section{IIMIIECONF}

4th International Conference On Research In

factors (current mood, pressure of limited buying time, the appearance of the sales object, the kindness of the sales staff etc.). A significant part of the total retail turnover is achieved based on impulsive buying. On the basis of a greater number of research carried out in the time period 1945-2015, it has been determined that between $38 \%$ and $60 \%$ of all retail buying is performed impulsively, and in case of specific product categories even up to $80 \%$ (Ling \& Yazdanifard, 2015).

Today, different contexts of $\mathrm{Y}$ generation are being discussed, referring to people born after 1980, and before 2000, while different sources are not fully concordant when it comes to the stated time span. For example, in USA and in Brasil Y generation refers to people born between 1981 and 2001, while on the other hand, in Russia and the Czech Republic, the stated generation refers to the time span between 1983 and 2000. Also, it is estimated that on a global scale there are 1.8 billion people worldwide belonging to the $\mathrm{Y}$ generation (Valentine \& Powers, 2013). In Anglo-Saxon literature this generation is known as the Why Generation, iGeneration, e-Generation, while the last term is also connected with the $\mathrm{Z}$ generation (all people born during the second millennium). In that sense the term i-Generation can creatively be regarded as an acronym from the syntax impulsive generation. The term $\mathrm{Y}$ generation is owed to the name of the previous generation, the generation $X$, which was known by its expressed self-assurance, pragmatism, high expectations regarding work and cynicism (WMFC, 2019). Today, the members of the Y generation are a part of the global population of young people which lead the consumer society and significantly influence the global economy. Because of this, the $\mathrm{Y}$ generation is in the focus of big companies and marketing experts, especially when it comes to the creators of public opinions, popular bloggers and trend setters. According to the data of Goldman Sachs (2019), the Y generation is showing expressed affinity towards new technologies, thus changing the retail concepts (for example, 57\% of them regularly compare prices within shops in the digital surroundings). Due to the specific lifestyle and continuous trend following, this generation can be described by the term impulsive.

The main aim of this paper is to determine the difference between male and female participants of the $\mathrm{Y}$ generation in the process of impulsive product and service buying. The impulsive buying includes all forms in order for the conclusions to be as precise as possible.

\section{Impulsive buying}

Impulsive buying is characterized by a spontaneous and sudden desire to shop for products and services (Maričić, 2011). Impulsive buying is buying which occurs without the previous intention to buy a certain category of product or appears as the result of the tendency of the consumer to urgently satisfy the currently arisen need (Beatty \& Ferrell 1998). The usual buying process of the consumer assumes that there are five connected stages: (1) need recognition; (2) gathering information on different alternatives; (3) the evaluation of different alternatives and the selection of the alternative; (4) buying a product or a service; and (5) grading it after the performed buying. In case of impulsive buying need recognition and buying performance are directly connected phases, i.e. the consumer does not gather information and does not take into consideration other alternatives, but instead performs buying spontaneously, buying the currently available product (Tine, 2010). 


\section{IIMIICONF}

4th International Conference On Research In

The four main characteristics of impulsive buying which are significant for its explanation are (Ling \& Yazdanifard, 2015): (1) it is buying which is not planned in advance; (2) it appears as a result of consumer exposure to external stimulus which influences the buying performance (attractive price, special product design, noticing some special characteristics of the product which is important for the consumer etc); (3) skipping two phases of the buying processgathering information on different alternatives and the evaluation of different alternatives before making the final decision on buying; and (4) it can be the result of cognitive reaction (the consumer can act rationally at a certain moment since he/she has noticed some characteristics of the product which creates a high level of value) or an emotional reaction (when the consumer reacts affectively to a stimulus without a cognitive engagement).

The reasons, factors and characteristics of impulsive buying are a subject of numerous research. For example, the study by Verplanken \& Sato (2011) analyzes the process of impulsive buying within a wider psychological configuration of the consumer, bearing in mind the self-regulation of individual behavior expressed within the theory offered by Higgins (1997, 1998, 2002) tending to unify the numerous aspects of this form of buying. In that context, the study defines two strategies of behavior self-regulation while impulsive buying, one with the focus on promotion (for example, the satisfaction seeking by the consumer), and the other focusing on prevention (for example the lack of consumer self-confidence).

Muruganantham \& Bhakat (2013) have intended to perform a historical retrospective of expert papers and scientific articles concerning the consumer impulsiveness while buying. Amongst those articles, one article stands out and concludes that impulsive buying is a special subject of interest within the emerging countries, due to intensive development of retail markets and present cultural differences compared to developed economies (Kacen \& Lee, 2002). The growth of available income and individual credit ability (especially in the case of $\mathrm{Y}$ generation), as well as the changes within the lifestyle have attributed that the impulse buying would become a wide-spread phenomenon. Bearing in mind the stated papers, it is possible to conclude that it is necessary to create an attractive offer and pleasant atmosphere within the very sales object in order for the consumers to stay longer and to perform as much impulsive buying as possible (Đorđević \& Marinković, 2019).

Impulsive consumer buying is directly under the influence of personal characteristics of the individual and external factors of influence onto it (Youn \& Faber, 2000). There are consumers who are, due to personal characteristics, more prone to impulsive reactions which are more often of affective than of cognitive nature, younger people are more prone to impulsive buying than the older ones, there are cultures which affect the greater affinity to impulsive buying, people with more expressed materialistic characteristics of personality are less prone to impulsive buying etc. (Wells et al. 2011). Vishnu and Raheem (2013) have analyzed the impulsive consumer behavior depending on the independent variables based on which several key external factors of influence on impulsive buying have been identified: promotion activities at the very point of sales, the interior of the shop, the shop window appearance, the level of income and the credit potential of the consumer. Their study concludes that buyers are extremely prone to impulsively shop for fast moving consumer goods, especially in case of discount offers and price decrease. Impulsive buying is significantly contributed by higher individual budget, efficient merchandising, well designed interior, pleasant and relaxing 


\section{IIMIIECONF}

4th International Conference On Research In

surroundings and arranged exterior surroundings. In that manner positive perception is aimed to be created with consumers, which later on creates a mental image about the need of impulsive buying, thus solving the dilemma (if the dilemma ever existed).

Within their empirical analysis, Hossain \& Hoque1 (2015) show the concept of the so-called super store sales object which shall be able to answer the demands of consumers traditionally prone to minimum time spent during buying. The paper states a set of factors which form the consumer perception and influence his/her decision: the location, the internal atmosphere, the distribution of the points of sale, product availability, buying ease, quality of products, brand availability, the size of the object, the image of the merchants, offer diversity, discounts and sales, products soon to be expired, the volume of stocks, buyer recommendations, package, TV screens etc. Besides, specific and general buying, as well as substitute availability, influence the frequency and probability of carrying out impulsive buying. If that is added by insufficient interest of Y generation for a voluminous and long term procurement of needed staples than the frequency of impulsive buying increases, while the product scope and the paid amount also increases. Based on all stated, the group of authors has determined that there is a positive and proportional correlation between the frequency of visiting the super store objects and the value of impulsive buying, which practically opens up a completely new segment and the feeling of the market for big retail chains.

\section{Y Generation and impulsive buying}

Y generation represents a special market with it's own characteristics, which is greatly connected with the concept of impulsive buying. The basic characteristics of the Y generation are: the desire for achievement, consumption orientation, civil obedience, self-confidence, favoring differences, expressed need for hedonism, tolerance, competitiveness, drawing attention, socializing, cosmopolitanism, technological awareness, realistic global perception (WMFC, 2019). Stated values have been influenced by numerous circumstances which have grown into influencers, i.e. typical factors which form the consciousness of people, such as: digital media, focus on children and young people, frequent divorces, the desire to change a bad order, the submission to economic principals, swiftness at home and at work, facing the growing threats portrayed by international terrorism, contagious diseases, migratory crises and constantly present geo-political tensions.

Without the previously stated, the Y generation is characterized by consumer mentality and unsatisfied need for buying, in order to satisfy the growing needs and desires. Those features can be linked to a specific type of impulsive buying, defined by Stern (1962) as pure impulsiveness, the effect of remembering and the planned buying of a specific type, but not the brand of product. Besides, in order to perform such a buying, adequate mood and consumer thrill is needed, in order to simply surrender to the psychological stimulus coming from outside.

According to a research carried out several years ago by the Princeton University (New Jersey, USA) (2018), the Y generation brings with it advanced technical skills, specific consumer experience and availability of the global market at any place. Its members are highly 


\section{IIMIICONF}

4th International Conference On Research In

ambitious, willing to compete and prove themselves confident of their abilities. That makes them highly motivated, independent and optimistic at work. Such an attitude is also prevalent in the domain of consumption, since ultimate and current satisfaction are aimed to be achieved at everything. The principle of success at any cost is usual when it comes to the behavior of most millennials. For example, success at consumption can be measured by the level of hedonistic fulfillment, thus often identifying impulsive buying with emotional consumption. Within the modern society, emotional decision making is especially expressed with millennials, which is another indicator of the readiness of Y generation to perform impulsive buying.

During the last two decades, research which have been dealing with similar themes have not been carried out in a great number, with the majority that have been performed mostly focusing on the analysis of individual factors of influence onto the behavior of Y generation when it comes to impulsive buying, rather than an integral approach. The group of authors (Khan et al., 2015) has carried out an empirical study among 250 participants of the Y generation with the aim to analyze impulsive buying at stores selling clothes and shoes. The results have shown that gender had the greatest influence on the decision of impulsive buying, along with external and personal factors. On the other hand, this study concluded that income and extroversion as a consumer personal characteristics have not significantly stimulated impulsive buying.

Within one other study (Shin et al., 2015), using a sample of 330 respondents of the Y generation, factors of influence on impulsive buying have been analyzed while performing buying in e-stores. The results of the statistical analysis have shown that web page design, eservice offered by the company, privacy and consumer security significantly influence the electronic impulsive buying.

The second research performed on a sample of 150 respondents carried out by Santhi \& Aruna (2015) explains that the main drivers of impulsive buying are current trends, fashion role-models and instant pleasure, rather than the socio-economic background of the consumer. Within their research, the participants of the $\mathrm{Y}$ generation have mostly been recognized as consumers prone to expensive and popular brands ready to take risks and hedonistic at work. As such, they are more prone to unplanned and sudden actions compared to previous generations.

Sharma \& Datta (2017) have also carried out an empirical research focused on the participants of the Y generation. Based on their research, it has been concluded that impulsive buying is dominantly influenced by the consumer mentality of the $\mathrm{Y}$ generation along with demographic and socio-economic factors. The elements which separate the Y generation from the previous generations are different taste and preferences while impulsive buying, mainly of branded clothes $(21,8 \%$ of respondents), shoes (15,5\% of respondents), food and drinks $(16,4 \%$ of respondents) and movies (12,7\% of respondents). 55,5\% of respondents have impulsively shopped for a product or brand they have practically never heard of before, while around 38,2\% have bought a familiar brand, that was not intended to be bought at that moment. The decision on impulsive buying is influenced by the combination of external (for example the quality and design of product category) and internal stimuli (for example, curiosity and the sense of being „trendy"). The study has shown that the participants of the Y generation impulsively shop in the following situations: when they are happy- more than $16 \%$, after work- around $16 \%$, when 


\section{IIMIIECONF}

4th International Conference On Research In

they feel hunger- around 13\%, during free time and when hanging out with friends- around $10 \%$, while least of them shop impulsively when they are in a hurry- around $8 \%$ or when they are in a bad mood- less than $7 \%$.

\section{The methodology of empirical research}

In order to perform additional analysis of the phenomenon of impulsive buying among $\mathrm{Y}$ generation, an empirical research has been carried out. The research has been conducted in Serbia on a sample of 150 participants. The questionnaire contained two groups of questionsthe general ones and the specific ones. The general questions referred to the characteristics of the respondents: year of birth, gender, level of education, current working status and average financial expenditures for buying on a monthly level. The specific questions from the questionnaire were structured according to 5 types of impulsive buying foreseen by the Stern model: (1) pure impulsiveness; (2) the suggestion effect; (3) planned impulsiveness; (4) the remembering effect; and (5) planned buying of certain category, but not the product brand. The aim of this question group was to encompass all categories of impulsive buying defined by Stern (1962). The questionnaire included the following categories of products which can be the subject of impulsive buying: (1) Fast moving consumer goods- food products, cosmetics, home chemistry, appliances; (2) fashion products- clothes, shoes and fashion accessories; (3) products of new technologies- smart phones, tablets, tv sets, digital devices.

The intention of authors of the paper was to determine the differences in the process of impulsive buying among male and female consumers. The gathered data were processed and analyzed based on the Independent Samples Test, using the SPSS software.

\section{The results of the empirical research}

In accordance with the previously defined independent variables on one hand and the chosen specific questions on the other, a statistical testing has been carried out. In accordance with the aims of the research and the specific questions from the questionnaire, three research hypothesis have been set.

Hypothesis 1. Hypothesis 1 has been defined with the intention to determine weather men spend more financial funds, at average, on impulsive buying, compared to women. Hypothesis 1 has been defined in the following manner:

Ho: Men and women at average spend an equal amount of financial funds on impulsive buying at a monthly level.

$\mathrm{H}_{\mathrm{A}}$ : Men and women at average do not spend an equal amount of financial funds on impulsive buying at a monthly level.

Based on the Independent Samples Test a 2- tailed significance of 0.537 has been obtained. Since the value of significance is higher than 0.05 (the confidence interval), it can be concluded that an alternative hypothesis $\left(\mathbf{H}_{\mathbf{A}}\right)$ is rejected, and the zero hypothesis $\left(\mathbf{H}_{\mathbf{0}}\right)$ accepted, i.e. men 


\section{IIMIIECONF}

4th International Conference On Research In

and women at average spend an equal amount of financial funds on impulsive buying at a monthly level. Regarding by gender, the average monthly expenditures on consumption are almost the same with men and women. The biggest number of male and female respondents spends around $20 \%$ to $30 \%$ of their monthly income on impulsive buying.

Hypothesis 2. Hypothesis 2 has been defined with the intention to determine weather the average value of monthly impulsive buying with women of lower, middle or higher level of education differs from the average value of monthly impulsive buying with men of higher or university level of education. Hypothesis 2 has been defined in the following manner:

Ho: The average value of monthly impulsive buying with women of lower, middle or higher level of education does not differ from the average value of monthly impulsive buying with men of higher or university level of education.

$\mathbf{H}_{\mathrm{A}}$ : The average value of monthly impulsive buying with women of lower, middle or higher level of education differs from the average value of monthly impulsive buying with men of higher or university level of education.

According to the 2-tailed significance value less than 0.05 (the confidence interval) it can be concluded that the zero hypothesis $\left(\mathbf{H}_{\mathbf{0}}\right)$ is rejected, and the alternative hypothesis $\left(\mathbf{H}_{1}\right)$ accepted, i.e. that the average value of monthly impulsive buying with women of lower, middle or higher level of education differs from the average value of monthly impulsive buying with men of higher or university level of education. Based on the hypothesis, it can be concluded that more educated women spend more than more educated man.

Hypothesis 3. Hypothesis 3 has been defined with the intention to determine weather there is a difference between unemployed men and women regarding impulsive buying of a wide range products which are on sale or have discounts. Hypothesis 3 has been defined in the following manner:

Ho: Unemployed women of middle and higher education impulsively shop for a wide range of products which are on sale or have discounts equally as unemployed man of middle and higher education.

$\mathbf{H}_{\mathrm{A}}$ : Unemployed women of middle and higher education do not impulsively shop for a wide range of products which are on sale or have discounts equally as unemployed man of middle and higher education.

According to the 2-tailed significance value less than 0.05 (the confidence interval) it can be concluded that the zero hypothesis $\left(\mathbf{H}_{\mathbf{0}}\right)$ is rejected, and the alternative hypothesis $\left(\mathbf{H}_{1}\right)$ accepted, i.e. that the unemployed women of middle and higher education impulsively shop more for a wide range of products which are on sale or have discounts compared to unemployed man of middle and higher education.

\section{Conclusions}

Based on the theoretical and empirical testing, it can be concluded that the Y generation represents a special market segment which significantly satisfies its needs and desires by performing impulsive buying. Impulsive buying is influenced by numerous factors 


\section{IIMIIECONF}

4th International Conference On Research In

(demographic, personal, situation) which direct the participants of the Y generation to some basic types of impulsive buying- pure impulsiveness, the suggestion effect, planned impulsiveness, the remembering effect; and planned buying of certain category, but not the product brand.

The phenomenon of impulsive buying with its features significantly corresponds to the behavior and the consumer habits of the participants of the $\mathrm{Y}$ generation, both globally and in the case of Serbia. That is confirmed by a numerous research and studies which have dealt with finding the mutual connection between the Y generation on one hand and impulsive buying on the other. In the greatest number of cases, there is an established positive correlation between the very act of impulsive buying of the $\mathrm{Y}$ generation and the set of factors which influence the decision making. Therefore, the $\mathrm{Y}$ generation can be regarded as a unique promoter of impulsive buying within the dynamic and uncertain surroundings.

The additional confirmation to the mentioned studies are also the results of the field research carried out on a sample of 150 participants within the territory of Serbia, which confirm the expressed orientation of the $\mathrm{Y}$ generation towards impulsive buying.

The research has several limitations. First of all, it has been carried out in Serbia and the conclusion can not be generalized onto a wider population. Second, the research was of general character, although the research questions encompassed several categories of products. A deeper analysis of impulsive buying for the precise product categories would have much more importance. Third, the analysis aimed to determine the differences between men and women is of general character and did not include the deeper insight of motives and factors which influence it, which should be taken into account within future research.

\section{References}

Cichocki, A. and Unbehaven, R., (1993). Neural Networks for Optimization and Signal Processing, 1st ed. Chichester, U.K.: Wiley.

Beatty, S. E. and Ferrell, M., (1998). Impulse Buying: Modeling its Precursors, Journal of Retailing, Vol . 74, No. 2, pp. 169-191.

Đorđević, A. and Marinković V., (2019), Upravljanje potrošačima: Pristup baziran na vrednosti, CID Ekonomski fakultet u Beogradu, Belgrade.

Goldman Sachs, Millennials Coming Age, (2019). http://www.goldmansachs.com/ourthinking/pages/millennials/

Hole, D., Zhong, L. and Schwartz J., (2010). Talking About Whose Generation? Why Western generational models can't account for a global workforce, Deloitte Review, No 6, p 88- 98.

Hossain, A. And Hoque1, I., (2015). Perceptions of Consumer Impulse Buying Behavior in the Super Store: A Case Study of Some Selected Super Store in Bangladesh, Asian Social Science; Vol. 11, No. 9. pp. 68-76.

Kacen, J. and Lee, J., The Influence of Culture on Consumer Impulsive Buying Behavior, Journal of Consumer Psychology, Vol. 12, No. 2, pp. 163-176. 


\section{IIMIICONF}

\section{4th International Conference On Research In MANAGEMENT AND ECONOMICS}

Khan, N., Hui H., Chen B. and Hoe H., (2015). Impulse Buying Behaviour of Generation $Y$ in Fashion Retail, International Journal of Business and Management, Vol. 11, No. 1, pp. 92107.

Ling, L. And Yazdanifard, R., (2015). What Internal and External Factors Influence Impulsive Buying Behavior in online Shopping?, Global Journal of Management and Business Research, Vol. 15, No. 5., pp. 25-32.

Maričić, B., (2011). Ponašanje potrošača, CID Ekonomski fakultet u Beogradu, Belgrade.

Muruganantham, G., and Bhakat, R., (2013). A review of impulsive buying behavior. International Journal of Marketing Studies, Vol. 5, No. 3, pp. 149-160.

Santhi P. and Aruna S., (2015). Impulse Purchase Behaviour Among Generation-Y, The IUP Journal of Marketing Management, Vol. 14, No. 1, pp. 1-22.

Sharma, B. and Datta, D., (2017). Impulse Purchase Behavior Among the Millennials at Agartala Tripura in India, International Journal of Marketing \& Financial Management, Vol. 5, No. 6, pp. 01-15.

Stern, H., (1962). The Significance of Impulse Buying Today, Journal of Marketing, Vol. 26, No. 2, pp. 59-62

Shin, S., Qi, W., Chuen, K., and Teng Y.W., (2015). The Influencing Factors On Generation $Y$ Online Impulsive Buying Behavior, A research project submitted in partial fulfillment of the requirement for the degree of University Tunku Abdul Rahman. (http://eprints.utar.edu.my/1509/1/The_Influencing_Factors_On_Generation_Y_Online_Im pulse_Buying_Behavior.pdf)

Princeton University News, (2018), USA, http://www.princetonone.com/news/PrincetonOne\%20White\%20Paper2.pdf

Tinne, W. S. (2010). Impulsive purchasing: A literature overview. ASA University Review, Vo. 4. No. 2., pp. 65-72.

Valentine, D. and Powers, T., (2013). Generation Y values and lifestyle segment, J. Consum. Market. Vol 30, No.7, pp. 597-606.

Verplanken B. and Sato A., (2011). The Psychology of Impulse Buying: An Integrative SelfRegulation Approach, Research Article in Journal of Consumer Policy, No. 34, pp. 197-210.

Vishnu P. and Raheem A., (2013). Factors Influencing Impulse Buying Behavior, European Journal of Scientific Research, Vol. 100, No 3, pp. 67-79.

Wells, J., Parboteeah, V. and Valacich J., (2011). Research Article Online Impulse Buying: Understanding the Interplay between Consumer Impulsiveness and Website Quality, Journal of the Association for Information, Vol. 12, No. 1, pp. 32-56.

WMFC (2018), Generation Differences Chart, USA, http://www.wmfc.org/uploads/GenerationalDifferencesChart.pdf

Youn, S., \& Faber, R. J. (2000). Impulse buying: Its relation to personality traits and cues. Advances in Consumer Research, No. 27, pp. 179-185. 